Xavier Llovet Vilà

University of Bergen

DOI: http://dx.doi.org/10.5617/adno.5443

\title{
Language Teacher Cognition and Curriculum Reform in Norway: Oral Skill Development in the Spanish Classroom
}

\begin{abstract}
To better understand language teaching, there is a need to carry out research on teacher cognition, that is, to find out what teachers know, believe, and think, how they access these cognitions, and how they draw on them. This study examines how the intended curriculum reform is implemented in the Spanish as a second foreign language classroom in Norwegian lower secondary schools. More specifically, the study focuses on how teacher cognition about language teaching and learning shapes the development of oral skills. Using a mixed method research approach, seven Spanish language teachers in $8^{\text {th }}$ grade were initially interviewed, thereafter observed for four consecutive lessons, and finally interviewed again to gain further insight into the rationale in their teaching practices. The data analysis manifested a gap regarding the curriculum intention and the implementation observed. In the articulation of the principles of their teaching, teachers provided evidence of the ways in which their prior beliefs about language, teaching and learning from schooling, and professional teaching experiences powerfully influenced the extent to which they implemented the curriculum. This study highlights the need (1) to reconsider the design of current pre-service language teacher training programs, (2) to provide continuous teacher training and teacher development opportunities to in-service language teachers, and (3) to clarify both the intention and the operationalization of the language subject curriculum reform if it attempts to bring about change.
\end{abstract}

Keywords: Teacher Cognition/Teacher Beliefs, Classroom Observation, Oral Skills, Foreign Language Teaching, Spanish Didactics, Curriculum Reform. 


\section{Lærerholdninger og Kunnskapsløftet (K06): Utvikling av muntlige ferdigheter i spanskundervisningen}

\section{Sammendrag}

For å kunne forstå språkundervisning bedre er det behov for å forske på lcererholdninger, det vil si, å finne ut hva lcererne vet, tror og tenker, og hvordan de får tilgang til og benytter seg av denne kunnskapen. Denne studien undersøker hvordan den intenderte lcereplanen er implementert i spanskundervisningen ved norske ungdomsskoler. Mer spesifikt tar studien sikte på å undersøke hvordan lcererholdninger til språklcering og språkundervisning former utviklingen av muntlige ferdigheter. Ved hjelp av en kombinasjon av kvalitative og kvantitative metoder ble sju spansklæerere på 8. trinn intervjuet og deretter observert i løpet av en toukers periode, før de ble intervjuet på nytt for

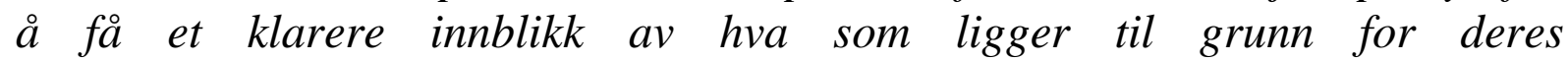
undervisningspraksis. Resultatene viser et gap mellom intensjonene i lareplanen og den observerte undervisningen. Lcerernes egne formuleringer av prinsipper $i$ egen undervisningspraksis, viste at deres tidligere oppfatninger om språk, undervisning, og språklcring, både fra egen skolegang og som profesjonelle lcerere, påvirket dem sterkt med tanke på i hvilken grad de implementerer lcereplanen. Denne studien understreker behovet (1) for å revurdere utformingen av lererutdanningsprogrammer ved universiteter og høyskoler, (2) for å gi utviklingsmuligheter til lcerere for etter-og videreutdanning og (3) for å avklare både definisjonen og operasjonaliseringen av lereplanen dersom lereplanreformen forsøker å få til endring.

Nøkkelord: larerholdninger, klasseromsobservasjon, muntlige ferdigheter, fremmedspråkundervisning, spansk fagdidaktikk, lcereplanreform

\section{Introduction}

Despite the growing interest in language teacher cognition specially in the last 20 years, the attention paid to specific domain areas such as oral skill development (spoken production and spoken interaction) is very limited (Baker, 2014; Baker and Murphy, 2011; Cohen and Fass, 2001). From a geographical perspective, research on teacher cognition has been mainly carried out in English speaking countries, rarely on languages other than English, and with a minimal insight into state school settings (primary and secondary) where languages are mainly taught by non-native speakers of the target language to large classes of learners (Borg, 2003). It is difficult to find an immediate 
explanation for this research gap given the relevance of oral skills in foreign language learning and teaching.

In Norwegian lower secondary schools, there is a difference in status between English which is the first foreign language for all pupils (L2), starting in primary school, and second foreign languages (SFL) such as Spanish, German and French (L3), introduced in lower secondary school but not compulsory. The implementation in Norway in 2006 of the school reform the Knowledge Promotion [Kunnskapsløftet (K06) in Norwegian] suggested that SFL teaching was to have a practical approach. According to the initial formulation by the Ministry of Education and Research a "practical approach to foreign language teaching means that the pupils learn to communicate in different ways and at different language levels" (UFD, 2007, p.35). Despite the Norwegian Directorate for Education and Training repeatedly attempted to clarify the meaning of a practical approach in curricular guidelines (UD, 2007, 2011, 2012), several reports and investigations have pointed out that both the definition and its operationalization are unclear, and can lead to multiple interpretations (Bugge and Dessingué, 2009; Heimark, 2013; Simensen, 2005; Solfjeld, 2007). In light of this framework of methodological freedom, teaching practices are open to the individual teacher's understanding, skill, and expertise since there is no clear application of the foreign language subject curriculum's assumptions and principles in the classroom. Hence the need to explore the impact of teacher cognition on teaching practices in relation to the role of curriculum innovation. Despite curriculum innovation attempts to bring about change and improvement within a specifically given society and culture, it may be the case that an implementation gap occurs and that change in education never takes place (Supovitz and Weinbaum, 2008). Thus, this article examines the relationship between an intended curricular reform in Norwegian lower secondary schools and its implementation in the Spanish as second foreign language (hereafter SSFL) classroom. The following research questions are addressed here ${ }^{1}$ :

- What are teachers' cognitions about the teaching/learning of Spanish in the context of a curriculum reform?

- How is the teaching of oral skills shaped by these cognitions?

\section{Curriculum reform and language teacher cognition}

From a theoretical and international perspective, the principal paradigm shift over the past 40 years in second language education was based on a move away from the tenets of behaviourist psychology and structural linguistics toward cognitive, and later, socio-cognitive psychology and more contextualized, meaning-based views of language (Richards and Rodgers, 2014). As a 
consequence, in a broad sense, the second language teaching and learning paradigm is described as a transition from a focus on form to a focus on meaning. The former paradigm implies mastery-oriented methodological approaches which emphasize the production of accurate samples of language use (product-oriented), whereas the current paradigm implies the use of more activity-oriented approaches which emphasized the interactive and communicative classroom processes (process-oriented) (Jacobs and Farrell, 2001). According to Richards and Schmidt (2010), in foreign language methodological terms, the former paradigm embraced what is known as the Audiolingual Method and the current paradigm is embodied in the umbrella term Communicative Language Teaching (CLT).

Likewise, from a theoretical but from a national perspective, it has been argued that the language paradigm shift has also taken place in Norway. Simensen $(1999,2007)$ claims that the theoretical principles behind the current paradigm were progressively introduced into the syllabus guidelines from the 1970s until the recent K06 educational reform. However, even though this education reform embodies the theoretical principles of the current paradigm, teachers have freedom to interpret and enact its content. On the one hand, Heimark (2013) also claims that, from a theoretical perspective, a practical approach can be seen as a subcategory of Communicative Language Teaching. On the other, from an operative perspective, there has been research questioning the actual enactment of the current paradigm in the SFL classroom both internationally (e.g. Jacobs and Farrell, 2001; Nunan, 1987; Van Patten, 1998) and nationally (e.g. Heimark, 2013; Lindemann and Speitz, 2002; Solfjeld, 2007). Given the mismatch between theory and practice, Bryman (2006) argues that paradigm shifts do not occur abruptly but smoothly over time. Thus, it seems more appropriate to envision the language paradigm shift not as a radical substitution but as a continuum in which teaching practices might be reflected.

Hence, in order to better understand the implementation of theoretical intentions, there is a need to examine teachers' internal cognitive processes, and focus on the "unobservable cognitive dimension of teaching - what teachers know, believe, and think” (Borg, 2003), namely, language teacher cognition. It has been affirmed that teachers are "rational professionals who make judgements and decisions in an uncertain and complex environment" (Shavelson and Stern, 1981, p.456). These decisions involve "complex, practically-oriented, personalised, and context-sensitive networks of knowledge, thoughts, and beliefs" (Borg, 2003, p.81). In addition, beliefs are deemed "to be true, and they serve as cognitive filters that interpret new experiences and guide teacher's thought and behavior" (Mohamed, 2006, p.21). Borg (2015) argues that language teacher cognition is influenced by an interacting network of schooling experiences, professional coursework, contextual factors, and classroom practice. In addition, there is evidence that teacher cognition about language and language teaching is influenced by previous own experiences as a learner 
(Lortie, 1975). These experiences are long-lasting and resistant to change (Almarza, 1996; Pajares, 1992), they have a strong influence on how teachers behave in the classroom and vice versa (Meijer et al., 1999), they are influenced by contextual factors (Richards and Pennington, 1998), and they may not correspond to what teachers do in their teaching practice (Golombek, 1998; Woods, 1996). Hence, language teaching can be seen as a process which is defined by dynamic interactions among cognition, context, and experience.

There is numerous research to indicate that curriculum reform does not necessarily guarantee a significant improvement in the quality of education, especially when it comes to communicative oriented language teaching (e.g. Breen et al., 2001; Karavas-Doukas, 1996; Kırkgöz, 2008; Mangubhai et al., 2004; Orafi and Borg, 2009; Yan, 2012). For instance, Karavas-Doukas (1996) pinpoints that communicative oriented teacher training courses that ignore teacher beliefs may lead to teachers returning to their classrooms, misinterpreting the new ideas received, and translating them to conform to their existing routines, believing that they might be following what the new approach suggests. Breen et al. (2001) revealed that teachers shared a finite set of principles of action, suggesting the existence of a collective ideology in which principles might be hierarchically ordered being more or less resilient in relation to peripheral or contextual factors. In this vein, Richards (1996) states that teachers develop personal principles that inform their approach to teaching, which he calls teacher maxims. This rationale of beliefs and values serves as the background to teacher decision-making and action and hence constitutes what has been termed the culture of teaching (Richards and Lockhart, 1994). Research carried out by Kırkgöz (2008) reveals that prior specific teacher training had an impact on the extent of teachers' implementation of a communicative oriented curriculum in primary education. Interestingly, all participating language teachers were qualified but those with a lack of systematic training to teach young learners showed a fragmentary understanding of CLT principles which in turn made it difficult for them to leave the security provided by traditional methods. Orafi and Borg (2009) provided evidence about the power exerted by teachers' prior beliefs about language teaching and learning on teaching practices. Such lack of congruence between the intended and the enacted curriculum was mainly due to external factors to the teachers, such as low oral communication skills, traditional classroom roles based on teacher control, or a traditional systematic preconception of assessment. Such is also the case of research carried out by Yan (2012), which in a general sense summarizes and reflects the aforementioned findings. The implementation gap found was due to a set of interrelated factors such as traditional teaching practices due to a lack of teacher training but also to the Chinese culture of teaching, student resistance to new methodologies, lack of school support, and backwash examination effect. 
The interest in the study of language teacher cognition in secondary schools in Norway has exponentially increased in the last ten years (Bugge and Dessingué, 2009; Claussen, 2011; Drew et al., 2007; Gilje, 2014; Haukås, 2012; Heimark, 2013; Hestetræet, 2012; Larssen and Drew, 2014; Solfjeld, 2007; Uthus, 2014). In particular, the extensive study around the definition and implementation of a practical approach carried out by Heimark (2013) sets the theoretical framework for the identification of a practical approach with a subcategory of CLT and thus, comprised within the current paradigm. From a practical perspective, CLT aims at developing students' communicative competence by engaging them in meaning-focused communication through the performance of tasks. In foreign language theory, communicative oriented practice has to be arranged for learners to work towards the communicative objectives of the curriculum, engage learners in communication, and require the use of such communicative processes as information sharing, negotiation of meaning, and interaction (Richards and Rodgers, 2001, p.165). In addition, from a communicative and interactionist perspective (Hatch, 1978; Pica, 1987; Swain, 1985), participant organization involving group work is considered to be essential in the development of communicative competence, since students are encouraged to negotiate meaning, to use a greater variety of linguistic forms and functions to develop overall fluency skills. Further, one of the arguments made in the language teaching literature regarding language skills is that students should be encouraged to integrate their language skills practice to reflect a more authentic use of language (Nunan, 1989). In order to promote language learning and proficiency in the target language, tasks and activities should involve the practice of productive skills (speaking and writing) in class. Nevertheless, regarding the development of oral skills in the Norwegian SFL classroom, Heimark (2013, p.229) clearly states that there is a considerable gap between teaching practices and the theoretical principles underlying communicative oriented teaching. Contrary to what is claimed in teachers' statements, the findings in Heimark (2013) show that oral language use plays a smaller part in the respondents' actual teaching. Particularly, the use of the target language, especially in spontaneous and open-ended utterances, is minimal. Instead, teachers tend to prefer the use of short writing activities and the oral production of previously prepared written texts. In conclusion, the Norwegian SFL community seems to be facing a mismatch between current theoretical principles and actual teaching practices. These considerations set the stage for this investigation.

\section{Method}

In order to identify teacher cognitions about the teaching and learning of Spanish, and how they shape oral skill development practices, a case study form 
was chosen because it "investigates a contemporary phenomenon in depth and within its real-life context” (Yin, 2014, p.237). In particular, this multiple-case design followed a descriptive, interpretive, and mixed method approach (Cohen et al., 2007). Qualitative and quantitative data collection methods were used, the former through interviews to elicit teacher cognition (Dörney, 2010), and the latter through classroom observation to code for teaching practices (Allen et al, 1984). The pragmatic approach of this study opted for a holistic and inclusive stance whereby the choice between the two research models addressed reliability, validity, and generalizability concerns. There has been a clear attempt to generate a transparent audit trail (Lincoln and Guba, 1985; Miles and Huberman, 1994), which shows as much as possible the rationale and procedures that have led to a particular set of conclusions (Seale, 1999). Likewise, multiple sources, instruments, and techniques to encourage convergent lines of enquiry were also employed to triangulate gathered data facilitating thus the establishment a chain of evidence. Finally, as suggested by Cohen et al. (2007) to address criticism for unrepresentative data given the limited number of informants in the study, there has been an attempt to develop a rich and robust narrative of the findings to allow events speak for themselves and not be misguided by large interpretations, evaluations or judgements.

\section{a) Participants}

The participants of this study consisted of seven in-service SSFL teachers working in Lower Secondary Norwegian schools (8th grade). Teachers were gathered through an email collaboration request to the Norwegian Association of Teachers of Spanish (ANPE) and also to principals in lower secondary schools in the Hordaland county area, for proximity reasons. There was no need to select the seven teachers as they were the only ones who volunteered and met the only criterion of the study, namely, teaching SSFL in $8^{\text {th }}$ grade Norwegian lower secondary schools. The reason for selecting $8^{\text {th }}$ grade is to be found in the fact that it is the first encounter students have with the second foreign language. They all had varied profiles in terms of academic background, teaching experience, age, gender, and mother tongue as shown in the table below. Names have been changed to maintain anonymity: 
Table 1. Summary of teacher information

\begin{tabular}{|c|c|c|c|c|c|c|c|}
\hline Teacher & Age & $\begin{array}{l}\text { Mother } \\
\text { Tongue }\end{array}$ & $\begin{array}{l}\text { SSFL } \\
\text { Experience } \\
\text { (n=years) }\end{array}$ & $\begin{array}{l}\text { ECTS } \\
\text { points } \\
\text { in SSFL }\end{array}$ & $\begin{array}{l}\text { PGCE } \\
\text { (PPU) }\end{array}$ & $\begin{array}{l}\text { School } \\
\text { Funding } \\
\text { \& Area }\end{array}$ & $\begin{array}{l}\text { Number } \\
\text { Students in } \\
\text { School } \\
\text { \& per class }\end{array}$ \\
\hline T1-Marie & $50-65$ & Norwegian & 6 & 90 & Yes & $\begin{array}{l}\text { Public } \\
\text { Suburban }\end{array}$ & $\begin{array}{l}\sim 500 \\
20-25\end{array}$ \\
\hline T2-Pedro & $30-40$ & Spanish & 2 & 0 & Yes & $\begin{array}{l}\text { Public } \\
\text { Suburban }\end{array}$ & $\begin{array}{l}\sim 500 \\
20-25\end{array}$ \\
\hline T3-Cristina & $40-50$ & Spanish & 7 & +180 & No & $\begin{array}{l}\text { Private } \\
\text { Urban }\end{array}$ & $\begin{array}{l}\sim 100 \\
\max .12\end{array}$ \\
\hline T4-Marta & $50-65$ & Spanish & +10 & +180 & Yes & $\begin{array}{l}\text { Public } \\
\text { Urban }\end{array}$ & $\begin{array}{l}\sim 500 \\
20-25\end{array}$ \\
\hline T5-Ingrid & $30-40$ & Other & +10 & 210 & Yes & $\begin{array}{l}\text { Public } \\
\text { Urban }\end{array}$ & $\begin{array}{l}\sim 500 \\
25-30\end{array}$ \\
\hline T6-Aslak & $50-65$ & Norwegian & 7 & 60 & No & $\begin{array}{l}\text { Public } \\
\text { Urban }\end{array}$ & $\begin{array}{l}\sim 400 \\
20-25\end{array}$ \\
\hline T7-Silje & $30-40$ & Norwegian & 3 & +180 & Yes & $\begin{array}{l}\text { Public } \\
\text { Urban }\end{array}$ & $\begin{array}{l}\sim 500 \\
20-25\end{array}$ \\
\hline
\end{tabular}

Their academic background ranged from no specific European Credit Transfer System (ECTS) points in SSFL (Pedro) to MA in Spanish (Ingrid). Five had completed the Postgraduate Certificate in Education (PGCE, PPU in Norwegian) and their teaching experience varied from two to fifteen years. Three of them were native Spanish speakers.

The six schools that conform the sample in the study (Marie and Pedro worked at the same institution) is similar in several aspects. First, there is a concentration of institutions in Hordaland County (except Cristina's school in Akershus County) mainly because of proximity reasons with the researcher. Secondly, institutions are mainly publicly funded (except the school in Akershus County), which is the status of the majority of schools in the Norwegian schooling system. However, the inclusion of such one small institution located in a different part of Norway, adds an interesting dimension to the data (smaller number of students per class with special education needs) since the common average of 25-30 students is very regular among public institutions, and also among the sample in this study.

\section{b) Data collection and analysis}

Data was collected over two periods of three months each with a year of difference among them. Non-participant classroom observations (Van Lier, 1988) and semi-structured interviews (Dörney, 2010) were used. Although observation is an effective strategy in the study of language teacher cognition, it is not enough to provide an accurate basis for teaching practices. Verification for researcher's inference must be sought through further sources of data such as the 
use of verbal commentaries to get teachers to talk about what they think, know or believe (Borg, 2015). Likewise, as suggested by Creswell (2003), lesson plans and teaching materials were also collected to triangulate gathered data to strengthen the construct validity of case study research.

Over each data collection period, two types of semi-structured interviews were carried out with each participant. One hour general background interview took place prior to four consecutive classroom observations in order to elicit general information about: (1) the teacher (age, academic background, experience, etc.), (2) the teaching context (the institution, expectations, restrictions, etc.), (3) instructional material (satisfaction, extra material, resources, etc.), (4) reflections on teaching (self-perceived strengths/areas to improve, lesson planning, etc.), and (5) the new subject curriculum (in relation to teaching materials, to planning, to practice, etc.). The set of 35 questions proposed were used as an open question guide to the topics for each of the five aforementioned sections. The primary data was audio recorded, then transcribed within the same day using the voice recognition program Dictation included in OSX 10.9.5 to speed up the process, and finally crossed checked and amended by the researcher. The second step involved non-participant classroom observation (four consecutive lessons of 50 minutes each) of the same teacher with the same group of students. An adapted version of part A of the Communicative Orientation of Language Teaching (COLT) scheme (Spada and Fröhlich, 1995) was developed to code for observed teaching practices to provide a macroscopic description of L2 classrooms at the level of activity types and the interactions within them. The adaption consisted in adding four new coding subcategories that were not contemplated in the original COLT scheme, which emerged from the particularities of the Spanish SFL curriculum such as to code for student-computer interaction, and/or non-linguistic skill development (numeracy, metacognitive, or digital skills). Among the most relevant general categories found in COLT, there is participant organization (class, group, individual), content focus (language or management) and control (teacher/text, teacher/text/student, student), developed language skills (speaking, listening, reading, writing), and materials used (type and source). The basic units of analysis of classroom-based data collection were activities, and episodes within activities, that involved the production by the learner of systematic verbal utterances to convey meaning (Bailey, 2005, p.48). While observing and coding for activities, a video camera was also being used. In addition to the COLT observation scheme and audiovisual recordings, field notes were occasionally taken to document events not captured by the recording. Finally, after each classroom observation, the third step involved interviewing teachers for 20 minutes also using an open semi-structured 12 question guide to clarify and elicit the rationale behind observed practices. These post-observation interviews focused on three topics: (1) planning implementation, (2) lesson content and structure, and (3) student involvement. The rationale behind these themes was to 
make the cover overt and contrast views between the observer and the teacher about the observed lesson to maximize data collection validity and reliably when triangulated with observation schemes and audio and video recordings.

The procedures used to analyze data reflect the circular process and nature of qualitative research, in which data collection, analysis, interpretation, and reporting proceed in a recursive and iterative manner (Cohen et al., 2007). Current literature on communicative oriented language teaching (e.g. Ellis and Shintani, 2014) suggested initial categories for the analysis of teaching practices such as focus on meaning, type and source of input, opportunities for output, and gap based interaction opportunities, all of them general coding categories present in COLT. While some of these categories were retained for the data analysis, other categories like sequence (Shrum and Glisan, 1994; Richards and Rodgers, 2014), language use (Prabhu, 1987), and task dimension (Littlewood, 2004) were added as they emerged from the analysis. Sequence codes for the stage within a lesson the activity takes place (pre-opening, opening, presentation, guided practice, communicative practice, closure, follow-up and closedown). Language use registers whether speaking practices deployed focus on the reproduction, borrowing, or production of verbal formulations. Production is self-initiated verbal formulation, resulting from a deployment of linguistic competence, it is automatic, and with attention remaining on the meaning-content expressed (e.g. authentic communication). Borrowing is taking over a verbal formulation to express some self-initiated meaning-content, it is deliberate, and a matter of saying what one wants to say in someone else's words (e.g. use a given exponent from the teacher/course book/peer to express an idea). Reproduction's purpose is, wholly or partly, to take over an available sample of language and the decision to do so is in compliance with the requirement or expectation of the teacher (e.g. role-play a dialogue in pairs reading aloud, repeat aloud to practice pronunciation, etc.). Task dimension codes for degrees of focus on form or meaning. According to Littlewood (2004), a task moves along a continuum in which students may operate with differing degrees of form/meaning attention. This continuum moves from noncommunicative practice (e.g. substitution exercises), to pre-communicative practice (e.g. question-and-answer practice), to communicative language practice (e.g. information gap activities), to structured communication (e.g. structured role-play and simple problem-solving), and/or finally to authentic communication (e.g. creative role-play, complex, problem-solving and discussion). In addition, Littlewood's version was extended so that extra information could be provided when the specific task focus was on form, namely, whether there was an explicit (and/or combined) focus on vocabulary, grammar, or pronunciation.

Thus, a new and comprehensive tool for the specific analysis of speaking skill activities was developed, the Speaking Observation Scheme (SOS). This analysis tool included both a priori and emergent categories as a result of the 
abductive approach adopted, which tried to be extremely careful not to impose a priori categories but to be also open to the emergence of new categories that might not have been initially considered (Silverman, 2015). A progressive focusing approach Verschuren (2003) was followed whereby each stage of data analysis informed the subsequent stage. For example, the initial emerging analysis developed from the simple process of taking notes, transcribing and digitalizing interviews and observations, to a more detailed attempt to develop categories of analysis (i.e. schooling, professional coursework, contextual factors, and classroom practice), moving deeper into understanding, representing, and making an interpretation of the larger meaning of the data (Bryman, 2004; Cohen et al., 2007). Through the analysis, fragments of transcripts were given certain names and labels using Nvivo. This enabled the identification and interpretation of the descriptions and explanations given by participant teachers, as well as it facilitated the construction and discovery of tacit, mutual knowledge, and symbiotic meanings and rules of behavior that provided orientations for participant teachers' actions (Blaikie, 2004).

The analysis consisted of three stages; documentation (transcription and digitalization of data, initial development of categories), conceptualization, coding and categorizing (reduction of data, organizing categories into a hierarchy of nodes in Nvivo, checking and refining categories), relationships' examination and data display (interpretation, theorizing, drawing conclusions, and display of emergent insights, both individually and cross case). Hence, data examination, interpretation, theorizing and final display were carried out in different but interrelated chronological periods.

\section{Findings}

The analysis of language teacher cognition about language learning and teaching evidenced an impact of previous language learning and professional coursework experiences (Borg, 2015). Teachers' utterances generally highlight that initial language learning is based on the command of formal aspects of the language (i.e. grammar and lexis) to be retrieved for oral use in later stages. The origin of such beliefs is to be found both in previous experiences as language learners and positively perceived accumulated experience. The alignment between cognitions and practices is evidenced in the task dimension (Littlewood, 2004) deployed in the activities registered to develop oral skills. The predominance of noncommunicative (substitution exercises focusing on language structures) and precommunicative practices (question-answer activities with some attention to meaning but not communicating new message to others) indicates a clear tendency towards forms rather than to meaning. The tendency to adopt a product-oriented (Richards, 2013) view of language and language learning indicated an orientation towards the former paradigm. A representative sample 
of teachers' accounts provided in this section, both cognitions and practices, is presented below.

\section{a) Teacher Cognitions about Language and Language Learning/Teaching}

The following passages from two experienced teachers, Marie (T1) and Aslak (T6), reveal similar focus on forms cognitions when prompted to talk about lesson objectives after classroom observation:

I use to say to my students that this (pointing to the head) is a hard disk and that we have to fill it in with lots of knowledge because it's not until 10th grade when they can look for this knowledge in order to write a good text or perform well in a role-play. They have to know a good deal before they can perform properly in a role-play. We put in knowledge and we say that. So, I mean, we do put knowledge in their heads and we try to put them in a context afterwards. And that's difficult. (T1)

You know, what makes it difficult is that students have to have a base in order to be able to speak and we want them to come forward and speak, I mean, once they begin to be active in relation to vocabulary and sentence structure and so on, we see that in 10th grade they begin to be at this stage (...) but it takes a long time to get to this stage and therefore one has to work with structures, write a good deal, one has to learn uh and this is precisely what's difficult, to get a balance, because you'd like to have more focus on the oral part, but you have to build a base. (T6)

According to Marie and Aslak, speaking skill development is characterized by a clear focus on forms based on the idea that in initial stages extensive exposure to grammatical and lexical input is paramount to be able to produce at later stages. Thus, the command of formal aspects in the language is essential to speak, which reinforces the idea that input comes before output. Further, SFL learning is perceived as a transmission of declarative knowledge. The assumption of the validity of the banking model (Freire, 1993) brings about the development of low order thinking skills, namely, promoting the linear sequence between understanding, remembering, and applying presented input (Anderson et al., 2001).

Marie's (T1) cognitions about language and language learning seem to be influenced by her previous SFL learning experiences. While describing her experience learning German at high school, she realized that the key to language learning 'is simply the grammar, right? I can't think about the others without thinking first about myself, it's the base of all'. Such resistant beliefs are also reinforced by the relevance of teaching experience as she mentions 'there's when experience comes in, as a teacher. I don't have a 20 years' experience as a teacher, I wish I had (laughs) but it has to do with experience, with what we do, with what works'. Such is also the case of Aslak who mentions that 'I've already been teaching for eight years so I see that students have problems mostly with linguistic structures, right? I mean, vocabulary isn't a problem, it can be 
easily solved with dictionaries'. Thus, in order to address attention to form, the role of instructional material plays a key role. As he points out, experience has taught him to adapt instructional material to what he calls 'my way of teaching', so that the perceived lack of activities directed to the learning of grammar in the course book may be compensated by the creation and use of extra instructional material of his own.

As shown in the first two excerpts above, Marie's and Aslak's understanding of the learning process as a transmission of declarative knowledge is also found in the accounts of Pedro (T2):

I think that what's good is if at the end they understood, if they remembered the content they learned and in the next lesson they're able to use what they learned in the previous lesson. So, in this sense, this is what I think a good lesson is. If they could remember, use it and be able to keep on using it afterwards. That they remember. (T2)

Interestingly, unlike the rest of participant teachers, Pedro is the only teacher with almost no experience or academic background in SSFL teaching. It may be claimed that his perception of a good lesson is situated within the tradition of the former paradigm, where memorization and accumulation of knowledge was paramount. The impact of audiolingual tenets had an unwitting effect on his cognition (and practice) about language, and language learning and teaching. Repetition in order to remember the input presented emerges as a powerful belief, which in turn determines the development of SSFL speaking skills, namely, it emphasizes the product view of language learning. Note also that the promotion of lower cognitive skills (understanding, remembering, and applying) is being implicitly stated.

The former paradigm oriented understanding of language and language teaching/learning as a product is also reflected in the accounts of Marta (T4). During the general interview, she seems to realize, without having ever thought about it before, that teaching practices in the 8th grade tend to focus on 'the teaching of the language as such, the grammar and the structures of the language instead of the culture'. She argues that this might be because 'the teacher is aware that the student has a low level and that he/she's beginning to learn a language then uh the teacher focuses more on that the student learn the basic grammar'. Marta later reinforces this view on language and language learning, and states that 'the student should know- it should be well known that this is a system and uh how can I say that uh I tell my students that uh it can be learnt, that it's a system and that you can manage'. In addition, when prompted to talk about her own image as a teacher, Marta describes herself as a content matter expert because 'I have a strong knowledge of the subject', a language matter expert because 'I am a native speaker and I have the correct pronunciation', a provider of answers for the students because 'I can answer many of the questions students may have', an experienced teacher because 'I have experience and I know where Norwegian students may encounter difficulties', a 
general yet a detailed planner because 'I can plan according to a more general plan', and an evaluator and assessment expert because 'I am good at giving students assessment of where they are and where they should be going to'. It may be affirmed that Marta is a self-confident teacher, because she perceives she is a trained SSFL teacher, she is experienced, and she is a native speaker. However, a closer look reveals strong beliefs about the role of the teacher as a knowledge provider to a receptive student who is to learn accurately the target language. These beliefs initially originate from her schooling period where as a language learner 'there wasn't enough focus on the aspect of correct pronunciation', which is why it is emphasized (drilled) in her lessons, as well as from her professional coursework as shown above.

Such an understanding of language as a system in which a focus on forms has a preferential role is also shared by Ingrid (T5):

\begin{abstract}
$X L V$ Uh do you think that uh is it a good way of learning a language like the way you mention with a text, grammar uh exercises, fill in the gaps...?

T5 If I had to learn a new language now I would like it this way because I like to learn grammar and then the vocabulary, understanding the language as a system but uh to my students it doesn't work because they have no idea about grammar, they don't learn anything, they don't even know the difference between a noun and an adjective so I would completely lose them if I tried this way.
\end{abstract}

On the one hand, Ingrid has very clear ideas about how she learns a foreign language best. On the other, she is aware that, due to her teaching experience, her learning preferences do not apply to her students. During the interview, she repeatedly insists on the fact that since explicit grammar teaching does not work, it is preferably to be minimized. Conversely, according to her, vocabulary learning is to be maximized in initial stages. Thus, Ingrid's approach to SSFL teaching is to expose her students to plenty of decontextualized vocabulary learning opportunities through games. So far it may be claimed that the influence exerted by her teaching experience outweighs Ingrid's beliefs about the importance of grammar. Note also that Ingrid's nine-year experience in SSFL teaching in the lower secondary school context might positively reinforce the credit of such teaching practices, and in turn, perpetuate them. In addition, Ingrid is the most academically qualified participating teacher, which seems to confer safety and confidence, as she mentions. Thus, the combination of second language learning beliefs, academic background, and teaching experience become the base upon which to bring about a communicative oriented teaching practice.

The practices observed in the case of Cristina (T3) and Silje (T7) reflect the tension between the understanding of learning as a process, from a pedagogical stance, with the understanding of language as a product, from a foreign language didactics perspective. Cristina is a teacher very much influenced by a negative previous experience as a learner in general, and as a foreign language learner in 
particular. As she mentions, she grew up during dictatorship when errors were stigmatized. As a result, Cristina's language teaching approach, with regards to the student role, is very much reactionary to her teenage schooling experiences. Such an approach is reinforced by the particularities of the school and the students she is working with (low number of students in class who, in addition, have special education needs). Nevertheless, behind Cristina's explicitly stated student-oriented practices lies an understanding of the language as a system which is reflected when describing her ideal teaching material as a 'grammar book with a long text where I can read a story in Spanish'. Hence, 'long texts' are to present lexical and grammatical input in context, which is later complemented by a grammar book where eventual explanations of structural content appear.

Silje learnt Spanish in a natural context because she lived for four years in Latin America. Hence, the best way for her to learn a language is through immersion: 'the best of all is to learn it in the place where the language is spoken (...) this is how I learnt Spanish, for example, it's almost a kind of language bath so they say'. Furthermore, she emphasizes the relevance of orality when learning Spanish: 'If you actually want to be able to use the language then you need to both listen to it a lot but also to speak it uh so you need a lot of speaking training'. Given her experience learning Spanish abroad through immersion, she would like to reproduce in class the same authentic conditions for her students, but she is aware of the difficulties. This is notably relevant because it may be claimed that the immediacy of orality in natural contexts gives less room for reflection through, for example, written work, which is more common in educational contexts such as the SFL classroom. In this context, when prompted to talk about how to reproduce such a situation in non-natural contexts, Silje refers to the variety of learning styles in class but reiterates the role of writing, memorization, and repetition all related to vocabulary learning which unveil second language learning beliefs impacting on practices. In fact, one of the most recurrent topics in the general interview is the constant reference to written texts and the attention to semantic meaning of words. Thus, written texts from the course book function as the trigger (and also as the model for reproduction) to activate students in the derived reading, listening, writing, or speaking activities. In fact, this is how she defines the way her lessons are structured, which also points towards a presentation-practice-production (PPP) lesson structure.

\section{b) Main Features of Speaking Instruction}

The most common salient facets in speaking instruction presented in this article are related to two of the five categories in the Speaking Observation Scheme (SOS) used to code for classroom observation. These two categories are language use (Prabhu, 1987) and task dimension (Littlewood, 2004). The main features of observed speaking instruction regarding these two dimensions are: 
supported language reproduction and form-focused oral practice. Supported language reproduction responds to students' oral practice to reproduce a deliberate taken over verbal formulation of the provided samples with attention on language (Prabhu, 1987, p.61), which is mediated by a written text. Formfocused oral practice is the result of oral skill development which basically involved non-communicative and pre-communicative practices (Littlewood, 2004), that is, oral reproduction to specifically rehearse with grammar, vocabulary, and/or pronunciation. Hence the alignment with teacher cognitions regarding language learning as an accumulative process which involves mastering of linguistic features one by one (Ellis and Shintani, 2014, p.337). These emergent features must be understood as interwoven and complementary aspects within speaking instruction, which stem from a particular understanding of language, and language teaching and learning.

Given the uniformity of registered oral skill development practices among teachers, individual results are not presented. As shown below, this is due to the fact that the predominant speaking practice in all observed teachers is clearly focused on forms (Littlewood, 2004). More specifically, spontaneous oral use in teacher planned activities was never registered. The testimonial three meaningoriented episodes for student initiated and spontaneous oral production registered (birthday song to a fellow classmate (2) and game initiated by students (1)) contrast with the other 19 meaning-oriented episodes in which oral production was the result of student responses to teacher prompts at the beginning or the end of lessons (e.g. initial/final salutation, roster calling, etc.). According to Thornbury (2012), this supports the argument that authentic language use in teacher-centered classrooms does occur, but only at the interstices and marginalia of lessons.

\section{i) Supported Language Reproduction}

Due to the aforementioned attention to forms, learners' language use in oral skill development activities was mainly to reproduce (32 episodes), or to reproduce and borrow (19 episodes), while students produced in 22 out of the total 73 episodes registered.

Table 2. Percentage of speaking language use (Prabhu, 1987)

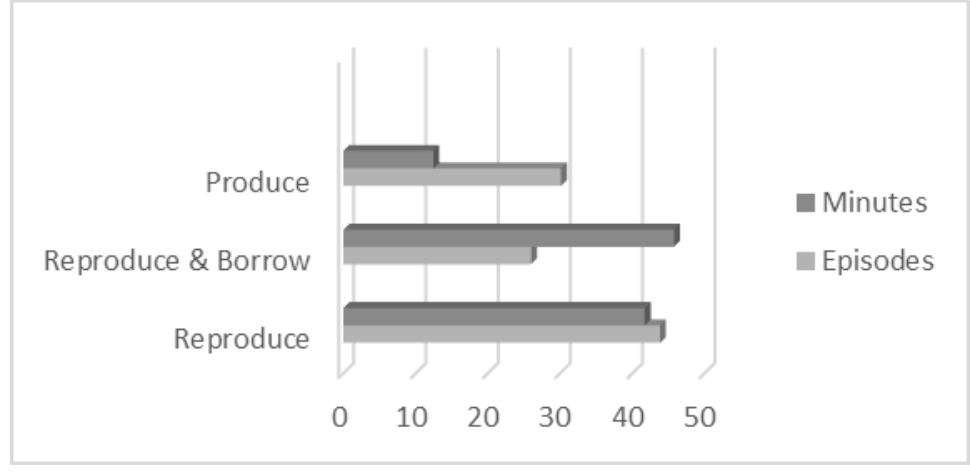


From a quantitative timewise perspective, the findings are striking. The time devoted to reproduction was 154 minutes, to reproduction and borrowing 169 minutes, while production performance totaled 46 minutes out of a final number of 369 minutes of speaking skill development. Consequently, students reproduced, and reproduced and borrowed 87.52 per cent of the time. It may also be affirmed that out of the total observation time (1460 minutes), students spent reproducing, and reproducing and borrowing 22.12 per cent of the time, while producing 3.15 per cent of the time. Students are offered approximately 1/4 of lesson time (369 minutes/1460 minutes) to develop oral skills. However, I prefer to draw the attention to the value of process-oriented research by considering the quality of the speaking skill development registered rather than its quantity, as shown below.

\section{ii) Form-focused Activities}

Evidence gathered from classroom observations reveals that the speaking task dimension coded in the SOS scheme clearly leaned towards a focus on forms (Littlewood, 2004). Out of the total 73 episodes, 37 involved noncommunicative learning, 17 pre-communicative language practice, 16 communicative language practice, and three authentic communication:

Table 3. Percentage of task dimension deployed in episodes registered (Littlewood, 2004)

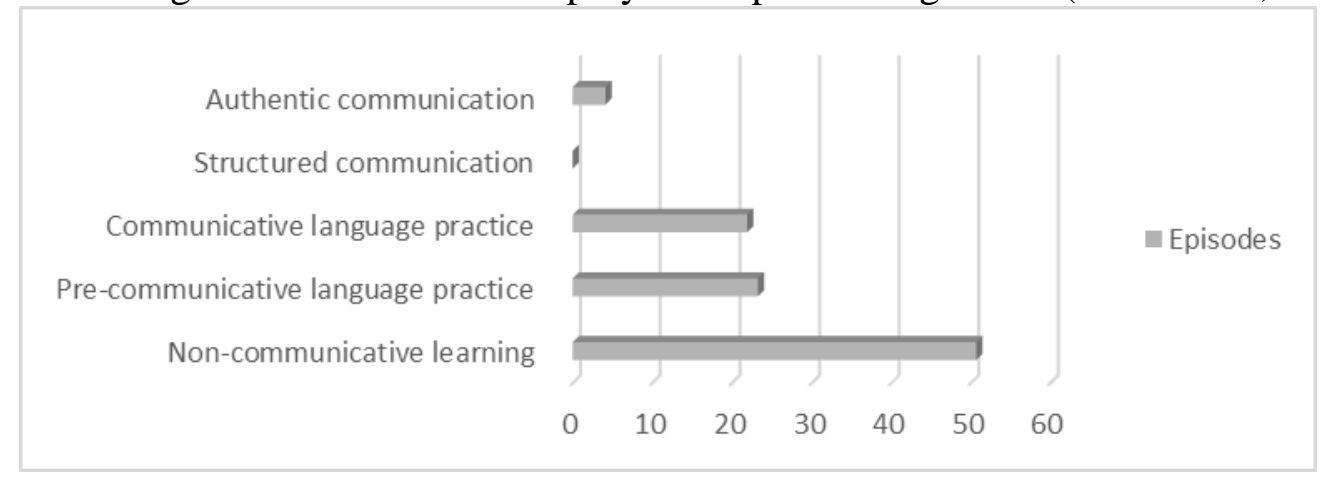

In other words, oral skill development is the result of former paradigm oriented practices which draw on a structural syllabus and involve teaching different language features at a time. As shown above, since teachers view language as a system of structurally related elements (phonemes, morphemes, words, structures, and sentence types) for the encoding of meaning, the speaking instruction derived assumes that the ability to speak fluently follows naturally from the teaching of grammar and vocabulary, with a bit of pronunciation thrown in. For instance, Marie and Pedro structure their teaching into blocks (grammar being one of them while observing), which explains why the objective behind the majority of their registered oral activities is grammar learning; Cristina and Silje believe in a structurally linguistic progression from simple to complex input, which explains the initial focus on vocabulary and pronunciation 
in oral activities registered before oral skill development oriented to grammar learning is introduced; Marta's oral skill development is clearly influenced by her concern for accuracy in pronunciation as almost all registered activities had a clear focus on pronunciation followed by translation; and finally, Ingrid and Aslak view language as a system in which grammar and vocabulary learning in initial levels is paramount. For Ingrid, explicit grammar teaching is to be minimized due to negative previous experiences, and thereby, vocabulary learning is to be maximized. Therefore, she provides students with grammatical exponents to be borrowed/reproduced in activities where vocabulary learning is the main objective. Instead, Aslak opts for oral skill development basically based on drilling pair work to practice with previously presented lexical and grammatical input. For all of them, as in audiolingualism, the importance of input before output is appreciated, or alternatively, there cannot be fluency without previous accuracy. Hence, the oral skill development registered basically involved the categories non-communicative learning and precommunicative language practice. Teacher planned communicative language practice (e.g. information-gap activities in which pre-taught language is practiced in a context where it communicates new information) was testimonial with two registered activities (Marta and Ingrid). As Long (2000) points out, oral skill development generally represented the last stage in discrete-point grammar teaching as it was based on the work with isolated linguistic structures in an externally predetermined sequence.

\section{Discussion}

One of the main objectives in the present study was to find out what teachers' cognitions about language and language teaching/learning are in the context of a curriculum reform. The evidence from this study indicates that teachers perceive language, and language teaching and learning from the former language paradigm stance. It can be claimed that language teacher cognitions originate early and tend to self-perpetuate (Lortie, 1975). For instance, in line with previous research, teachers' own language learning experience during schooling exerts a powerful impact on the cognitions of Marie, Marta, Cristina, Ingrid, and Aslak (Johnson, 1994; Numrich, 1996; Woods, 1996). Particularly for speaking, teachers accounted, implicitly or explicitly, for their pedagogical choices with references to maxims such as input before output (Bailey, 1996; Richards, 1996). These cognitions function as a catalyst through which teachers interpret new information and experience (Pajares, 1992). In this vein, teacher cognition and classroom practice exist in 'symbiotic relationships' (Foss and Kleinsasser, 1996) and interact bi-directionally with experience (Richardson,1996). However, tensions between cognitions and practices have also been observed. Ingrid, a firm believer in the importance of grammar and vocabulary for 
language learning, tended to minimize or even disregard explicit grammar teaching at the expense of vocabulary due to previous negative experiences in initial levels. These cognitions have proved to exert a strong influence on teachers' pedagogical decisions (Johnson, 1994) and seem to outweigh the effects of teacher education (Richardson, 1996). This is particularly important regarding the low impact initial teacher training education had on both cognitions and practices, which in turn, supports the argument that cognitions are deep-rooted and resistant to change (Almarza, 1996). It may be argued that such resistance is due to routines which have developed over time and which have been reinforced if they are felt to be successful (Nunan, 1992; Tsui, 2003), as this is how teachers perceive their teaching.

The impact of these cognitions on oral skill development is the second focus of attention in this study. The reproduction of oral utterances observed involved whole or partial (re)production of samples of language provided by the teacher (usually written on the blackboard) or from written prompts in course book activities. In other words, reproduction was a deliberate taken over verbal formulation of the samples with attention on language, which is of little value to language acquisition (Prabhu, 1987, p.61). Hence, the recommended spontaneous language use in SFL curricular reform (LK06) may not occur because the oral skill development encouraged did not allow self-initiated production. Only three episodes for student-initiated production were registered. The other 19 episodes in which production was registered occurred during management procedure passages in response to a teacher prompt at the interstices of the lesson. In line with Thornbury (2012, p.61), speaking is considered as a by-product of the knowledge of the systems of the language, namely, speaking means "oral production -or, better, oral reproduction- of language to which the learner had been previously exposed". Such oral practice is based on the assumption that "as long as the learner had amassed a sufficient store of grammar and lexis, and so long as some attention had been paid to the accurate phonological articulation of this stored knowledge, speaking would take care of itself” (ibid.). This assumption lies upon former paradigm beliefs about language, and language teaching and learning. In addition, language learning in initial stages is characterized by a bottom-up approach (Nunan, 1991, p.45), namely, a move from a mastery of the discrete elements of the language to a mastery of the larger components. Hence, teachers' understanding of learning is the development progressive view, rather than the immediate communication view (Bygate, 1987, p.56). As for oral skill development, teachers view language as the ability to speak it derived from the systematic study of grammar, phonology and lexicon (Rivers and Temperley, 1978). The influence of prior second language learning experiences, as well as the impact of previous teaching experience on teacher cognition and practice has proven to be extremely powerful. Thus, there is strong evidence that the speaking practices 
registered were strongly congruent with deeper underlying beliefs about language, learning and teaching.

So far, this study has provided evidence of the manner in which the adoption of the intended communicative oriented education reform may see its implementation limited due to the impact of schooling and professional background experiences on language teacher cognition. Thus, it can be overall affirmed that there is a high level of congruence between teachers' cognitions and practices. In the same vein, several studies, both in general and in language teaching education, have indicated that the manner in which curricula reforms are implemented in the classroom does not necessarily reflect how they were intended by their developers (e.g. Orafi and Borg, 2009; Sato and Kleinsasser, 1999; Supovitz and Weinbaum, 2008; Yan, 2012).

\section{Conclusion}

The results presented in this study show considerable differences between the communicative oriented intentions of the curriculum and the instruction observed in lower secondary schools in Norway. Consequently, results indicate a limited adoption by the seven SSFL teachers of a communicative oriented oral skill development in the classroom. Therefore, an implementation gap is claimed as the main finding of the study.

In addition, this study has revealed very interesting findings regarding teachers' identities, as regardless of age, gender, school, academic background, experience, mother tongue, or working conditions, they see themselves and how they enact their roles within different settings in a similar manner. I here also suggest the existence of a culture of teaching (Richards et al., 1992) within the SSFL community observed, namely, a common rationale of cognitions and values that serves as the background to teacher decision-making and action (Breen et al., 2001; Richards, 1996; Richards and Lockhart, 1994). Evidence provided in this study supports previous research (e.g. Heimark, 2013; Lindemann and Speitz, 2002; Solfjeld, 2007) regarding the existence of a wider common culture of teaching in the Norwegian SFL mainstream education context. However, note that extreme caution is to be administered given the generalizability issues derived from the limited number of participant teachers of this study. These are claims which merit further scrutiny in continuing research of this kind.

In order to address the claimed implementation gap, the point of departure is to acknowledge this gap and the reasons for it. Given the overriding influence of a practical approach from a national policy to the individual teacher level and considering the forthcoming K06 renovation in 2020, the implications suggested here, cover this three-dimensional scope: (1) implications for national authorities, (2) implications for teacher education institutions, and (3) 
implications for individual teachers within the SSFL community. As for national authorities, evidence from this study may serve as an initial analysis tool to inform the support systems which will be necessary to facilitate curriculum implementation. This in turn has obvious implications for teacher training programmes, and thereby, teacher education institutions. The findings in this study suggest that teachers have not yet been empowered with the necessary tools to bring about a practical approach, and thereby, intended change and improvement. Finally, as for individual teachers, the constitution of a community of practice (Richards, 2010) in schools, and by extension in municipalities, has to be addressed. It is thus essential that teachers are involved and interact to achieve common goals. Such goals may explore and resolve issues related to the common interest of the community members. Collaboration in the form of team teaching, peer observation or peer coaching (which are rarely performed in the Norwegian mainstream education context) in collaboration with higher education institutions and National authorities can help foster the sense of community of practice and bring about professional development.

\section{About the author}

Xavier Llovet Vila is Associate Professor at the Department of Foreign Languages, University of Bergen

Institutional Affiliation: Department of Foreign Languages, University of Bergen, Sydnesplassen 7, NO-5020 Bergen

E-post: xavier.llovet@uib.no

\section{References}

Allen, P., Swain, M., Harley, B., and Cummins, J. (1990). Aspects of classroom treatment: Toward a more comprehensive view of second language education. In Harley, B., Allen, P., Cummins, J., and Swain, M. (Eds.). The development of second language proficiency (pp.57-81). Cambridge: Cambridge University Press

Almarza, G. (1996). Student foreign language teachers' growth. In D. Freeman and J.C. Richards (Eds.). Teacher learning in language teaching (pp.50-78). Cambridge: Cambridge University Press.

Anderson, L. W., Krathwohl, D. R., and Bloom, B. S. (2001). A taxonomy for learning, teaching, and assessing: A revision of Bloom's taxonomy of educational objectives. New York, NY: Longman.

Bailey, K. M. (1996). The best laid plans: Teachers' in-class decisions to depart from their lesson plans. In K.M. Bailey and D. Nunan (Eds.). Voices from the language classroom (pp.15-40). Cambridge: Cambridge University Press.

Bailey, K. M. (2005). Practical English language teaching: Speaking. New York, NY: McGraw-Hill. 
Baker, A. (2014). Exploring teachers’ knowledge of second language pronunciation techniques: Teacher cognitions, observed classroom practices, and student perceptions. TESOL Quarterly, 48(1), 136-163.

Baker, A. and Murphy, J. (2011). Knowledge base of pronunciation teaching: Staking out the territory. TESL Canada Journal, 28(2), 29-50.

Blaikie, N. (2004). Abduction. In M.S. Lewis-Beck et al. (Eds.). The Sage encyclopedia of social science research methods (pp. 2-3). Thousand Oaks, CA: Sage Publications.

Borg, S. (2003). Teacher cognition in language teaching: A review of research on what language teachers think, know, believe, and do. Language Teaching, 36(02), 81-109.

Borg, S. (2015). Teacher cognition and teacher education: Research and practice (2nd ed.). London \& New York: Bloomsbury Academic.

Breen, M. P., Hird, B., Milton, M., Oliver, R., and Thwaite, A. (2001). Making sense of language teaching: Teachers' principles and classroom practices. Applied Linguistics, 22(4), 470-501.

Bryman, A. (2004). Social research methods. Oxford: Oxford University Press.

Bugge, H. E. and Dessingué, A. (2009). Rapport om “Språklæreres holdninger etter KL06”. Forskergruppe for fremmed- og andrespråksopplæring (FFAO). Stavanger: Universitetet i Stavanger.

Bygate, M. (1987). Speaking. Oxford: Oxford University Press.

Claussen, S. M. (2011). Erwerb von Gesprächskompetenz durch schulischen Fremdsprachenunterricht - ein erreichbares Ziel? Master's thesis, Universitetet i Tromsø, Tromsø.

Cohen, A. D. and Fass, L. (2001). Oral language instruction: Teacher and learner beliefs and the reality in EFL classes at a Colombian university. Ikala, Revista de lenguaje y cultura, 6(11-12).

Cohen, L., Manion, L., and Morrison, K. (2007). Research methods in education. New York: Routledge.

Creswell, J. W. (2003). Research design: Qualitative, quantitative, and mixed methods approaches (2nd ed.). California: SAGE Publications.

Dörney, Z. (2010). Questionnaires in second language research: Construction, administration, and processing (2nd ed.). New York: Routledge.

Drew, I., Oostdam, R., and van Toorenburg, H. (2007). Teachers' experiences and perceptions of primary EFL in Norway and the Netherlands: A comparative study. European Journal of Teacher Education, 30(3), 319-341.

Ellis, R. and Shintani, N. (2014). Exploring language pedagogy through second language acquisition research. London: Routledge.

Foss, D. and Kleinsasser, R. (1996). Preservice elementary teachers' views of pedagogical and mathematical content knowledge. Teaching and Teacher Education, 12(4), 429-442.

Freire, P. (1993). Pedagogy of the oppressed (2nd ed.). New York: Continuum.

Gilje, T. (2014). Teacher cognition and the teaching of EFL reading in Norwegian upper primary classrooms. Acta Didactica Norge, 8(2).

Golombek, P. R. (1998). A study of language teachers' personal practical knowledge. TESOL Quarterly, 32(3), 447-464.

Hatch, E. (1978). Second language acquisition: A book of readings. Rowley: Newbury House.

Haukås, Å. (2012). Lærarhaldningar til språklæringsstrategiar. Norsk Pedagogisk Tidsskrift, (2), 114-129.

Heimark, G. E. (2013). A practical approach in theory and in praxis. Lower secondary school teachers' understanding of a practical approach to the teaching of foreign languages. $\mathrm{PhD}$ thesis, University of Oslo, Oslo. 
Hestetræet, T. (2012). Teacher cognition and the teaching and learning of EFL vocabulary. In A. Hasselgren, I. Drew, and B. Sørheim (Eds). The young language learner: Researchbased insights into teaching and learning (pp. 177-190). Bergen: Fagbokforlaget.

Jacobs, G. M. and Farrell, T. S. C. (2001). Paradigm shift: Understanding and implementing change in second language education. TESL-EJ, 5(1), 1-16.

Johnson, K. E. (1994). The emerging beliefs and instructional practices of preservice English as a second language teachers. Teaching and Teacher Education, 10(4), 439-452.

Karavas-Doukas, E. (1996). Using attitude scales to investigate teachers' attitudes to the communicative approach. ELT journal, 50(3), 187-198.

Kunnskapsdepartementet (2006). Lœreplanverket for Kunnskapsløftet. Oslo: Utdanningsdirektoratet.

Kurkgöz, Y. (2008). A case study of teachers' implementation of curriculum innovation in English language teaching in Turkish primary education. Teaching and Teacher Education, 24(7), 1859-1875.

Larssen, D. and Drew, I. (2014). Student teachers' reflections on teaching English during a practice cycle. In A. Reinertsen, et al. (Eds.). FoU i praksis 2013 conference proceedings (pp. 161-169). Trondheim: Akademika forlag.

Lincoln, Y. S. and Guba, E. G. (1985). Naturalistic inquiry. Newbury Park, CA: Sage Publications.

Lindemann, B. and Speitz, H. (2002). Jeg valgte tysk fordi hele familien ville det, men jeg angrer. Status for 2. fremmedspråk i norsk ungdomsskole (Rapport 03/02). Notodden: Telemarksforsking.

Littlewood, W. (2004). The task-based approach: some questions and suggestions. ELT Journal, 58(4), 319-326.

Llovet Vilà, X. (2016). Language teacher cognition and practice about a practical approach: the Teaching of speaking in the Spanish as a foreign language classroom in Norwegian lower secondary schools. PhD thesis, University of Bergen, Bergen.

Long, M. H. (2000). Focus on form in task-based language teaching. In R. Lambert and E. Shohamy (Eds.). Language policy and pedagogy: Essays in honor of A. Ronald Walton (chapter 10, pp. 179-192). Amsterdam: John Benjamins.

Lortie, D. (1975). School teacher: A sociological study. Chicago: University of Chicago Press.

Mangubhai, F., Marland, P., Dashwood, A., and Son, J. (2004). Teaching a foreign language: One teacher's practical theory. Teaching and Teacher Education, 20(3), 291-311.

Meijer, P. C., Verloop, N., and Beijaard, D. (1999). Exploring language teachers' practical knowledge about teaching reading comprehension. Teaching and Teacher Education, 15(1), 59-84.

Miles, M. B. and Huberman, A. M. (1994). Qualitative data analysis: An expanded source book (2nd ed.). Thousand Oaks, CA: SAGE Publications.

Mohamed, N. (2006). An exploratory study of the interplay between teachers' beliefs, instructional practices \& professional development. PhD thesis, The University of Auckland, Auckland.

Numrich, C. (1996). On becoming a language teacher: Insights from diary studies. TESOL Quarterly, 30(1), 131-153.

Nunan, D. (1987). Communicative language teaching: Making it work. ELT Journal, 41(2), 136-145.

Nunan, D. (1989). Designing tasks for the communicative classrooms. Cambridge: Cambridge University Press.

Nunan, D. (1991). Language teaching methodology. New York, London, Toronto, Sydney, Tokyo, Singapore: Prentice-Hall International. 
Nunan, D. (1992). The teacher as decision-maker. In J. Flowerdew, M. Brock, and S. Hsia (Eds.). Perspectives on second language teacher education (pp. 135-165). Hong Kong: City Polytechnic.

Orafi, S. M. S. and Borg, S. (2009). Intentions and realities in implementing communicative curriculum reform. System, 37(2), 243-253.

Pajares, M. F. (1992). Teachers’ beliefs and educational research: Cleaning up a messy construct. Review of Educational Research, 62(3), 307-332.

Pica, T. (1987). Second language acquisition, social interaction, and the classroom. Applied Linguistics, 8(1), 3-21.

Prabhu, N. S. (1987). Second language pedagogy. Oxford: Oxford University Press.

Richards, J. C. (1996). Teachers’ maxims in language teaching. TESOL Quarterly, 30(2), 281-296.

Richards, J. C. (2013). Curriculum approaches in language teaching: Forward, central, and backward design. RELC Journal, 44(I), 5-33.

Richards, J. C. (2010). Competence and performance in language teaching. RELC Journal, 41(2), 101-122.

Richards, J. C. and Lockhart, C. (1994). Reflective teaching in second language classrooms. Cambridge: Cambridge University Press.

Richards, J. C. and Pennington, M. (1998). The first year of teaching. In J. C. Richards (Ed.). Beyond training (pp. 173-190). Cambridge: Cambridge University Press.

Richards, J. C. and Rodgers, T. (2014). Approaches and methods in language teaching (3rd ed.). Cambridge: Cambridge University Press.

Richards, J. C. and Schmidt, R. (2010). Longman dictionary of language teaching and applied linguistics (4th ed.). Harlow: Pearson.

Richards, J. C., Tung, P., and Ng, P. (1992). The culture of the English language teacher: A Hong Kong example. RELC Journal, 23(1), 81-102

Richardson, V. (1996). The role of attitudes and beliefs in learning to teach. Handbook of Research on Teacher Education, 2(01), 102-119.

Rivers, W. M. and Temperley, M. S. (1978). A practical guide to the teaching of English as a second or foreign language. Oxford: Oxford University Press.

Sato, K. and Kleinsasser, R. C. (1999). Communicative language teaching (CLT): Practical understandings. The Modern Language Journal, 83(4), 494-517.

Seale, C. (1999). Quality in qualitative research. Qualitative Inquiry, 5(4), 465-478.

Shavelson, R. J. and Stern, P. (1981). Research on teachers' pedagogical thoughts, judgments, decisions and behaviour. Review of Educational Research, 51(4), 455-498.

Shrum, J. and Glisan, E. (1994). Teacher's handbook: Contextualized language instruction. Boston, MA: Heinle and Heinle.

Silverman, D. (2015). Interpreting qualitative data. London: Sage Publications.

Simensen, A. M. (1999). Shifts of paradigm: A dilemma in foreign language didactics as a major component in the education of teachers. In B. Hudson, et al. (Eds.). Didaktik/ Fachdidaktik as science(-s) of the teaching profession? (vol. 2). Umeå: TNTEE Publications.

Simensen, A. M. (2005). Obligatorisk 2. fremmedspråk: En kjempeutfordring. Uniped, 1(28), 4-9.

Simensen, A. M. (2007). Teaching a foreign language principles and procedures (2nd ed.). Bergen: Fagbokforlaget.

Solfjeld, K. (2007). Andre fremmedspråk på ungdomstrinnet: Rapport fra en intervjuundersøkelse. Halden: Nasjonalt senter for fremmedspråk i undervisningen. 
Spada, N. and Fröhlich, M. (1995). COLT, Communicative orientation of language teaching observation scheme: Coding conventions and applications. National Centre for English Language Teaching and Research, Macquarie University, Sydney.

Supovitz, J. A. and Weinbaum, E. H. (Eds.) (2008). The implementation gap: Understanding reform in high schools. New York: Teachers College Press.

Swain, M. (1985). Communicative competence: Some roles of comprehensible input and comprehensible output in its development. In S. Gass and C. Madden (Eds.). Input in second language acquisition (pp. 235-253). Rowley: Newbury House.

Thornbury, S. (2002). Training in instructional conversation. In H. Trappes-Lomax and G. Ferguson (Eds.). Language in language teacher education (pp. 95-106). Amsterdam: John Benjamins.

Thornbury, S. (2005). How to teach speaking (6th ed.). Harlow: Pearson Education Limited. Thornbury, S. (2012). Speaking instruction. In A. Burns and J.C. Richards (Eds.). The Cambridge guide to pedagogy and practice in language teaching (pp. 198-207). Cambridge: Cambridge University Press.

Tsui, A. (2003). Understanding expertise in teaching. Cambridge: Cambridge University Press.

Utdannings- og Forskningsdepartementet (2007). Languages open doors: A strategy for promoting foreign languages in primary and secondary education, and training 20052009 (Technical report). Oslo: Kunnskapsdepartementet.

Utdanningsdirektoratet (2011). Veiledning til læreplan i fremmedspråk. Oslo.

Utdanningsdirektoratet (2012). Evalueringen av Kunnskapsløftet: 2006-2012 Utdanningsdirektoratets oppsummering av evalueringen (Technical report). Oslo.

Uthus, E. S. (2014). Learner response, teacher methodology and cognition on teaching L2 grammar at upper secondary school in Norway. Master's thesis, University of Stavanger, Stavanger.

Van Lier, L. (1988). The classroom and the language learner: Ethnography and secondlanguage classroom research. London: Longman.

Van Patten, B. (1998). Perceptions of and perspectives on the term "communicative”. Hispania, (2), 925-932.

Woods, D. (1996). Teacher cognition in language teaching. Cambridge: Cambridge University Press.

Yan, C. (2012). 'We can only change in a small way': A study of secondary English teachers' implementation of curriculum reform in China. Journal of Educational Change, 13(4), 431-447.

Yin, R. K. (2014). Case Study Research: Design and Methods. Thousand Oaks: Sage Publications

\footnotetext{
${ }^{1}$ The research questions in this article partially present the findings of a wider study. See Llovet Vilà (2016) for further information.
} 